\title{
The Impact of Contextual Factors on Learning of Agricultural Programmes in Technical and Vocational Education Training Colleges, South Africa
}

\author{
Ramongwane Daniel Sephokgole* \\ Tshwane University of Technology, Pretoria, South Africa \\ https://orcid.org/0000-0002-3600-0411 \\ Sylvia Manto Ramaligela \\ University of Limpopo, Polokwane, South Africa \\ https:// orcid.org/0000-0002-3200-2700 \\ Moses Makgato \\ Tshwane University of Technology, Pretoria, South Africa \\ https://orcid.org/0000-0002-9416-2777
}

\begin{abstract}
Contextual factors may influence the learning of agricultural programmes in Technical and Vocational Education Training (TVET) colleges. This study employed a quantitative approach to explore the impact of contextual factors on learning agricultural programmes in TVET colleges in the Limpopo Province of South Africa. The study surveyed 240 students from three TVET colleges. Purposive sampling was used to select the TVET colleges that offer agricultural programmes. Data was collected through a questionnaire to understand the impact of contextual factors on the students learning agricultural programmes. Data was analysed using Microsoft Excel 2016 and was presented in the form of a table. Based on Mitzel's (1969) model, the impact of the contextual factors will help to guide TVET colleges when recruiting agriculture students. The results of the study indicated that contextual factors such as the student's prior experience, knowledge, skills, and personality traits have an impact on the learning of agricultural programmes in TVET colleges. The study recommends that upon recruiting TVET students, contextual factors such as prior knowledge and skills, prior experience as well as personality traits should be tested.
\end{abstract}

Keywords: agricultural programme; contextual factors; prior knowledge and skills; prior experience; personality traits

*Corresponding author: Ramongwane Daniel Sephokgole; Email: SephokgoleRD@tut.ac.za 


\section{Introduction}

Learning has been a fundamental aspect of everybody's life since the creation of human nature and the need for learning agricultural programmes has been well documented (Kong, 2018). This motion of learning agricultural programmes has become a necessity for the students who are willing to work in farming and it has been supported globally (International Center for Tropical Agriculture [ICTA], 2015; International Fund for Agricultural Development [IFAD], 2016). A growing number of governments, donor agencies, and development organisations are committed to supporting the learning of agricultural programmes to achieve their development goals (Morss, 2019). Such goals were drawn from a deep concern about the status of Agricultural Education and Training (AET) worldwide. As a result of the importance of learning agricultural programmes, effective recruitment efforts are required to improve the number of students who are willing to register for agricultural programmes. However, the students' contextual factors such as prior knowledge and skills, prior experience and personality traits need to be considered.

Although recruitment is vital for the growing agricultural sector, identifying students who have interest in learning agricultural programmes is vital. Much research has been done on recruitment strategies, for instance, Ramson, Govender and Naidoo (2016) investigated the recruitment and retention strategies for public sector optometrists in the KwaZulu-Natal Province in South Africa. The study found that the incentives strategy was used to get a large proportion of optometrists. Malema and Muthelo (2018) also explored the strategies that may be utilised for the recruitment and retention of skilled healthcare workers in remote rural areas. The study found that compulsory measures on recruiting students were used and they were accompanied by relevant support and incentives to recruit health workers. Tanga and Maphosa (2018) in a separate study explored the recruitment and training of peer facilitators in a South African university. The study found that the critical factors in the recruiting strategy include the quality of peer facilitators and their level of academic attainment. Based on the studies above, most of the recruiting strategies focus less on the students' contextual factors which may have an impact on the learning of agricultural programmes.

A big variation continues to exist in different programmes and institutions, as students in TVET colleges are affected and influenced by various contextual factors and this impacts their learning (Mogensen \& Schnack, 2010). Therefore, the impact of contextual factors on learning agricultural programmes affects the status of Agricultural Education and Training. In the case of this study, the following question guides this research work: What is the impact of contextual factors on the learning of agricultural programmes in TVET colleges?

The researcher hypothesised that contextual factors include prior knowledge and skills, prior experience, as well as personality traits (Mitzel, 1969). Hence, this study emphasises that these contextual factors impact the students' learning of agricultural programmes in TVET colleges. This quantitative research method design was concerned with exploring the impact of contextual factors on the 
learning of agricultural programmes in three TVET colleges and providing recommendations to the relevant stakeholders.

Several researchers have noted the existence of contextual factors that influence learning and performance at large in various countries. Choi and Lim (2017) conducted a study on the contextual factors affecting the innovation performance of manufacturing medium-sized enterprises, while Imran and Pamungkas (2016) conducted a study in Indonesia on conceptualising the impact of contextual communication factors on organisational learning in higher learning institutions. Dang (2017) from Australia, explored the contextual factors shaping teacher collaborative learning in a paired placement. Although this subject has been researched in other countries, in South Africa, there are a few studies on agricultural programmes. For instance, Thwala (2017) conducted a study on an agricultural vocational education programme and the promotion of job creation skills in the Free State, while Zwane and Setlalentoa (2020) investigated the factors hindering the implementation of e-learning at Motheo Technical and Vocational Education and Training College. Sephokgole and Ramaligela (2021) wrote about the challenges experienced by lecturers when teaching about the instructional practices on agricultural programmes in TVET colleges. Hence, all these studies were aimed at exploring the impact of contextual factors on the learning of agricultural programmes.

\section{Theoretical framework}

To explore the impact of the contextual factors on learning agricultural programmes in TVET colleges, this study adopted Mitzel's (1969) model to investigate the related prospects of learning agriculture. This model is relevant as it can be utilised to explore the contextual factors impacting the agricultural programmes in TVET colleges. Mitzel's (1969) model provided the investigative framework to design this study and therefore, the contextual factors that are briefly considered are prior knowledge and skills, prior experience, as well as personality traits. To understand why students, choose to study agriculture, the study needs to understand the impact contextual factors have on learning agricultural programmes so that critical strategies can be created to evaluate these contextual factors. Extant literature mainly addresses the contextual factors that impact the learning of agricultural programmes.

\subsection{Prior knowledge and skills}

The term "prior knowledge and skills" has been used to understand the students' state of knowledge and skills in a particular programme. This study refers to prior knowledge and skills as content learned in the previous level of study (Mitzel, 1969). The two words, knowledge and skill are interrelated; hence, "prior knowledge" involves knowledge in particular agricultural topics, content, skills, beliefs, and cognitive understanding (McCarthy \& McNamara, 2021). This means "prior knowledge" does not just refer to subject-matter knowledge, but also to the "prior skills" of a particular subject matter. Xhomara (2020) also claims that prior knowledge and skills are closely connected. Therefore, many studies claim that prior knowledge is a component of performance, while performance portrays a successful virtue of one's skill (Sosa, 2015; Salzwedel, Heidler, Meng, Schikora, 
Wegscheider, Reibis \& Völler, 2019; Beatson, Berg \& Smith, 2020). This means prior knowledge and skills can influence the effectiveness of the students' learning (Taçgin, 2020). Other scholars also believe that prior knowledge and skills have a positive impact on learning in general (Chiu, 2016; Lin \& Liou, 2019). Therefore, students with knowledge and skills stand a better chance to recognise the subject matter and they can relate to new information using prior knowledge to apply the skills attached to the different learned content (Wati, Pasani \& Dewantara, 2018). Hence, the researcher believes in prior knowledge which can impact the learning of agricultural programmes.

As students enrolled in programmes in different TVET colleges, prior knowledge and skills were found to be an important factor when learning any programme (Yarden \& Yarden, 2010). According to Mothokoa and Maritz (2018), prior knowledge and skills help students to recognise some content that was learned in their previous schooling. Therefore, a study by Chiu (2016) noted that prior knowledge and skills have a direct impact and influence on understanding new learning content. Despite other reasons for students to choose to be involved in agricultural programmes, prior knowledge and skills are still among the contextual factors that impact the learning of agricultural programmes (Hoover, 2020). Several contextual factors have been identified in the extant literature which explains that personal interest, self-esteem, and societal influence are some of the major factors that significantly impact career selection (Pasha \& Siddiqui, 2019). Similarly, a study by Meddour, Abdo, Majid, Auf, and Aman (2016) found that self-efficacy, family, personal interests, and economic factors are considered amongst the contextual factors that may impact career choice. With regard to the aforesaid contextual factors, prior knowledge and skills are believed to be significant factors that impact the career choice of learning programmes (Deng, Guan, Huang, Liang, Zhang \& Zhang, 2017), it remains to be seen whether this holds across different learning programmes.

\subsection{Prior experience}

Prior experience is considered as an important learning factor for every student and as the most influential factor for choosing agricultural courses (Liaw, Wu, Chow, Lim \& Tan, 2017). A similar study conducted by Palmer and Aubusson (2017) notes that prior experience in agriculture was identified as the most relevant influential factor because most students choose subject careers based on their prior experience. On the same view, Kenderdine, Spooner, Jousan, Herrin and Hoffman (2019) opine that having prior experience increases the student's desire to obtain agriculture-related courses or participate in agriculture activities. For instance, Romberger (2018) conducted a study to compare secondary agricultural education students and secondary non-agricultural education students' perceptions of career decisions. The study found that prior experience on agricultural students reported higher self-efficacy scores when making career decisions on agriculture than non-agricultural education students. Therefore, there is a need to understand that the students' prior experience plays an influential factor and contributes to their decisions to choose agricultural programmes as their major career (Stair, Danjean, Blackburn \& Bunch, 2016). 
Furthermore, prior experience is among the factors that influence students to think about enrolling in agricultural programmes in TVET colleges (Hoover, 2020). The entire student's decision to choose a career in agricultural programmes is believed to be associated with prior experience factors (Perry, 2018). Furthermore, Marx, Smith, Smalley, and Miller (2017) believe that a passion for agricultural education does not only derive from prior experiences, but that other contextual factors can contribute to the students enrolled in other programmes. Several studies by Foreman, Smalley and Retallick (2018); s well as that of Mtemeri (2017) note that the other factors involved in the student's decisions to choose careers in agricultural programmes include but are not limited to career guidance, peers, current college students, agricultural educators, and family members.

Prior experiences can also build courage in a student's choice to study agriculture (Hoyle, 2017). A similar study conducted by Ingram, Sorensen, Warnick and Lawver (2018) found that the students' decisions were encouraged by prior experience in which the students were involved either in agriculture or other school-based subjects. Furthermore, Thieman, Rosch and Suarez (2016) conducted a study exploring the factors influencing the high school students' consideration of agricultural education as a future career. The study found that the students' involvement gave them prior experience that is related to the agriculture cocurricular and that encouraged the students' choice of furthering their career in agriculture. In the same view, Marx, Simonsen and Kitchel (2014) affirmed that prior experience serves as the most powerful factor to encourage the students' choice to study agriculture further.

According to Botha (2020), personal factors and prior exposure to job opportunities also play a major role in choosing to study agricultural programmes but prior experiences influenced the students' decisions to take agriculture as their first-choice career. For instance, Adebo and Sekumade (2013) conducted a study exploring the factors determining the choice of agriculture as a professional career. The study found that prior experience was among the preferred influential factors for choosing agriculture as a first career choice. Subsequent research has shown that throughout these years, the students still possess the intention that prior experience is an important factor that influences their choice (Fizer, 2013; Woeber \& Sibley, 2018; Bilal \& Hussien, 2019).

\subsection{Personality traits}

In a learning context, there is often a Five-Factor Model (FFM) that resembles personalities, including extraversion, openness, neuroticism, conscientiousness, and agreeableness (Ariani, 2013). There is considerable research about personality traits, but this research has yielded a single finding on the personality trait. In support of research, the student's interest in agriculture is linked to the extraversion personality traits (Ahmed, Sharif \& Ahmad, 2017). According to Ettis and Kefi (2016), extroverted students have stronger intentions to pursue their interests in studying agricultural programmes because they are more active in what they are doing. Similarly, Ariani (2013) opined that the extraversion personality traits are characterised by students who are ambitious and interested to achieve better and those traits can boost the students' attitudes to enrol in 
agricultural programmes. For instance, Picazo-Vela, Chou, Melcher, and Pearson, (2010) found a kind of attitude as the degree to which an individual student has a favourable or unfavourable trait towards learning agriculture.

One important element in learning is to have a positive attitude towards any learning content. Looking at the students' responses to the questionnaire, there is a relationship between personality traits and attitude (Kamal \& Radhakrishnan, 2019). However, Faulkner, Baggett, Bowen, and Bowen (2009) highlighted that the personality traits are necessary but not sufficient to influence the students' attitudes to enrol in a program of their choice. Furthermore, Kamal and Radhakrishnan (2019) assert that the students' personality traits help them to engage more in learning. Other scholars, however, found that the personality traits should be an important consideration when recruiting students because they contribute to academic performance (Zhang \& Ziegler, 2018; Stajkovic, Bandura, Locke, Lee \& Sergent, 2018; Kamal \& Radhakrishnan, 2019). Nevertheless, further research is needed to validate the results and to further understand the personality traits factor.

\section{Methodology}

Data collection, population, and sample, research instrumentation as well as procedures are considered in this section.

\subsection{Type of research}

This study used a quantitative research method to investigate the impact of contextual factors on the learning of agricultural programmes. Instruments such as questionnaires were used to collect information regarding the researched topic from one or more groups of agriculture students. The survey technique that was used here was directly administering questionnaires, which were given to a group of participants that were assembled for a particular purpose at a certain place. This quantitative research helped to generate knowledge and to create an understanding about the contextual factors on the learning of agricultural programmes.

\subsection{Population and sample}

According to Ary, Jacobs, Razavieh and Sorensen (2006), a study population includes all the members of any well-defined class of people, events, or objects. Gay, Mills and Airasian (2009) opine that a research sample includes a group of individuals, items, or events that represent the features of the larger group from which the sample is drawn. In South Africa, there are 50 TVET colleges, of which 13 are currently offering agricultural programmes. The Limpopo province has seven public TVET colleges, of which only three are offering agricultural programmes. It was impossible to include all the seven TVET colleges in the province in one study. Purposive sampling is a process of selecting the subjects who have experience, knowledge, and skills. Therefore, purposive sampling was used on the basis that the participants were information-rich regarding the agricultural programmes. Furthermore, convenience sampling is the process of including the participants that are available at the right place and at the right time. Hence the students were conveniently sampled based on their availability. 
Therefore, the general population of interest for this research was agriculture students.

This study is from my master's program which investigated the challenges of agricultural programmes in selected technical and vocational education training colleges in the Limpopo province. The reason for this research site was because it was convenient to reach, connected to the site and the researcher believes that the participants are rich in information that is related to agricultural programmes. The researcher was not sure of the other provinces that could give rich information on the research. The participating TVET colleges were given pseudonyms to protect their identities, therefore, they are referred to as Colleges A, B and C. The agriculture students were involved in the Technical Education Diploma (NATEDN1-N6) and in the National Certificate Vocational (NCV) agricultural programmes. A NATED program required at least three years of study with modules such as data management; financial management; maintenance management farming and management in farming. While the NCV program requires at least 3 years from level 2 to 4 , the modules include farm planning and mechanisation, plant production, animal production, soil science, and agribusiness. The other compulsory modules include English, Mathematics Literacy, and Life Orientation. The age of the participants ranged from 16 to 50 years (Males $=118$ and Females $=122$ ) and there were $49 \%$ males and $51 \%$ of the participants were females $(\mathrm{N}=240)$.

\subsection{Research instrumentation and procedure}

College A recorded 112 participants, College B recorded 84 participants and College $C$ recorded approximately 44 participants. A participant's demographic questionnaire was developed and used to collect sampled information. The questionnaire had three sections of which the first part was about biographical information that probed the gender, age group, and the program of involvement. The second part of the questionnaire had Likert-type questions. The research questions were generated from the literature to close the existing gap that was realised by the researcher. The five scores from the Likert scales were: $5=$ Strongly Agreed (SA), 4=Agreed (A), 3=Neutral (N), 2=Disagree (D), and 1=Strongly Disagreed (SD). This type of Likert scale helped the researcher to scaffold the data that was generated through the questionnaire. The participants were asked to indicate the extent to which they agree or disagree next to each statement by ticking the appropriate answer ( $\square)$.

The survey was administered as a paper-pen questionnaire and it was completed in about 40 minutes. The survey took place on different dates and occurred in a college where students assembled for a particular purpose at a certain place. The researcher gave each participant a copy of the questionnaire. For ethical purposes, the students were warned not to write their names on the questionnaire. However, the aim was to obtain reliable and valid information from the participants who had information that was related to the issue that was being studied. The instrument used in this study was reliable and valid. Reliability and validity in this research study represented the fundamental features that increase transparency and decrease bias (Singh, Fazel, Gueorguieva \& Buchanan, 2014). 
The researcher piloted the data collection instrument by making use of the students and the lecturers at the institution after which the researcher took the instrument to the supervisor who validated it. The researcher also employed peer and expert reviews to answer the questions in the questionnaire, after which the results that were arrived at were taken to the supervisor who measured the validity of the instrument. Microsoft Excel 2016 was used to analyse data. The analysis was based on the percentage result of the students' indication of each item of the questionnaire. The respondents' difference in opinion, perception, and experience and the results were presented in the form of tables.

\section{Results and discussion}

In this study, data was presented in the form of tables. The study deployed Mitzel's (1969) model as a framework and the categories were used to present the students' questionnaire results. The next section presents the students' biographical data, then it is followed by categories on prior knowledge and skills, prior experience, and personality traits.

\subsection{Biographical data}

The biographical data shows the gender of participants, their age group, and the program in which students are faced with contextual factors that affect the learning of agricultural programmes. The reason to present biographical data is to understand which gender of students, age group, and the program is mostly affected by competency on the learning of agricultural programmes. Table 1 below shows the students' biographical data.

Table 1. Students' biographical data.

\begin{tabular}{lll}
\hline Gender & Frequency $(f)$ & Percent (\%) \\
\hline Male & 118 & $49 \%$ \\
Female & 122 & $51 \%$ \\
Total & 240 & $100 \%$ \\
\hline Age Group & & \\
\hline $16-19$ & 10 & $4.1 \%$ \\
$20-30$ & 219 & $91.3 \%$ \\
$31-40$ & 8 & $3.3 \%$ \\
$41-50$ & 3 & $1.3 \%$ \\
Total & 240 & $100 \%$ \\
Above 50 & & - \\
\hline Program & & \\
\hline NC(V) & 156 & $65 \%$ \\
NATED & 84 & $35 \%$ \\
Total & 240 & $100 \%$ \\
\hline
\end{tabular}

The results show the frequency and the percentages of the three aspects, which are, gender, age group, and program. Firstly, under gender, the results indicated that $49 \%$ of the participants were male students and $51 \%$ were female participants in this research study. Secondly, under the age group, the results indicated that $4.1 \%$ of the participants were between $16-19$ years old, $91.3 \%$ were between $20-30$ years old, 3.3\% were between $31-40$ years old, $1.3 \%$ were between $41-50$ years old and no participants were above the age of 50 . Lastly, the results indicated that $65 \%$ of the participants were involved in National Certificate Vocational (NCV) 
training in the agricultural program, while $35 \%$ of the participants were doing a National Accredited Technical Education Diploma (NATED) in an agricultural program.

As indicated earlier that the study explores the students' contextual factors that impact the learning of agricultural programmes, the study deployed Mitzel's (1969) model as a framework and their categories were used to present data. The following section presents the findings and a discussion of the students' questionnaire. The survey results for the $(n=240)$ students were analysed and discussed in three categories of which Table 2 from item 1 to 4 shows the percentages responding to prior knowledge and skills. Table 3 shows item 1 to 3 and has the percentages responding to prior experience. Table 4 from item 1 shows the percentages responding to the students' personality traits from the questionnaire.

\subsection{Prior knowledge and skills}

To explore the students' prior knowledge and skills, the students were presented with four items that probe their prior knowledge and skills. Table 2 below shows the students' responses.

Table 2: Prior knowledge and skills

\begin{tabular}{|c|c|c|c|c|c|c|c|c|c|c|c|}
\hline \multirow{2}{*}{ Items } & Categories & \multicolumn{3}{|c|}{ SD } & \multicolumn{2}{|l|}{$\mathrm{D}$} & \multicolumn{2}{|l|}{$\mathrm{N}$} & \multicolumn{2}{|l|}{ A } & \multirow{2}{*}{$\begin{array}{l}\mathrm{SA} \\
\%\end{array}$} \\
\hline & Prior knowledge and skills & $f$ & $\%$ & $f$ & $\%$ & $f$ & $\%$ & $f$ & $\%$ & $f$ & \\
\hline 1. & $\begin{array}{l}\text { Students choose to } \\
\text { agriculture based on } \\
\text { knowledge and skills. }\end{array}$ & 10 & $5 \%$ & 23 & $10 \%$ & 34 & $15 \%$ & 92 & $38 \%$ & 79 & $32 \%$ \\
\hline 2 & $\begin{array}{ll}\text { Agricultural } & \text { Programmes } \\
\text { Offer Relevant } & \text { Agricultural } \\
\text { Knowledge } & \end{array}$ & 9 & $4 \%$ & 13 & $5 \%$ & 31 & $13 \%$ & 90 & $38 \%$ & 97 & $40 \%$ \\
\hline 3 & $\begin{array}{l}\text { Agricultural programmes offer } \\
\text { relevant agricultural skills. }\end{array}$ & 15 & $6 \%$ & 17 & $7 \%$ & 33 & $14 \%$ & 92 & $38 \%$ & 87 & $35 \%$ \\
\hline 4 & $\begin{array}{l}\text { Agricultural programmes help } \\
\text { to alleviate poverty, create } \\
\text { jobs, and minimize inequality. }\end{array}$ & 12 & $5 \%$ & 8 & $3 \%$ & 6 & $3 \%$ & 68 & $28 \%$ & 146 & $61 \%$ \\
\hline
\end{tabular}

Table 2 indicates that $32 \%$ of the students have strongly agreed and $38 \%$ agreed that they were influenced by prior knowledge and skills to study agriculture. Other results indicated that $15 \%$ of the students remained neutral, while $10 \%$ disagreed and 5\% strongly disagreed that they were influenced by prior knowledge and skills to study agriculture. The results show that a high percentage of the students chose to study agriculture based on prior knowledge and skills. Item 1 means that prior knowledge and skills play a major role in the choice of a career as shown by the majority of students who agree (38\%) and strongly agree (32\%). A child who possesses prior knowledge and skills of a particular subject will most likely choose agriculture as a career because they have a background in that subject. The $5 \%$ and $10 \%$ represent those who lack prior knowledge and skills related to their subject choice and they are most unlikely to choose agriculture as a career. The neutral students (13\%) seem to lack prior knowledge and skills and most likely, they will not take agriculture as a career. 
Most students (40\%) and the other 38\% showed strong agreement and agreement respectively on the fact that the agriculture programmes offered at TVET colleges impart relevant agricultural knowledge. The other results show that $13 \%$ of the students remained neutral, while 5\% disagreed and strongly disagreed that the agricultural programmes offered at TVET colleges impart relevant agricultural knowledge. The results indicated that a high percentage of the student's prior knowledge and skills make them understand that the agricultural programmes they were currently studying offer relevant agricultural knowledge. Item 2 means that the prior knowledge and skills that students possess, put them in a position to receive relevant agricultural knowledge as shown by the majority of the students who agree $(38 \%)$ and strongly agree $(40 \%)$. A student who possesses prior knowledge will want to learn more because they want to prosper in agriculture. The neutral students $(14 \%)$ seem to possess prior knowledge and most like they will not realise whether the agricultural programmes offer relevant knowledge or not.

A total of $(35 \%)$ TVET students strongly agreed and 38\% agreed that there were agricultural programmes that offered to impart relevant agricultural skills. The other results indicated that a total of $14 \%$ of the students remained neutral, while $7 \%$ disagreed and strongly disagreed that the agricultural programmes offered at TVET colleges impart relevant agricultural skills. The results show that a high percentage of the students' prior knowledge and skills make them understand that the agricultural programmes they were currently studying, offer relevant agricultural skills.

Item 4 on Table 2 indicated that most students $(61 \%)$ have strongly agreed and $28 \%$ agreed that agricultural programmes help to alleviate poverty, create jobs, and minimise inequality. The other results indicated that only $3 \%$ of the students remained neutral, while the other 3\% disagreed and 5\% strongly disagreed that agricultural programmes help to alleviate poverty, create jobs, and minimises inequality. The results show that a high percentage of the students' prior knowledge and skills help them to understand that agricultural programmes help to alleviate poverty, create jobs, and minimize inequality. Item 4 also means that the prior knowledge and skills help students to realize that agricultural programmes help to alleviate poverty, create jobs, and minimize inequality as shown by the majority of students who agree (28\%) and strongly agree $(61 \%)$. A student who engaged in agricultural activities before will most likely realise the contribution and importance of agriculture in life. The 5\% and 3\% represent those who were not exposed to agriculture before, and they are therefore unlikely to realise the contribution and importance of agriculture. The neutral ones $(3 \%)$ seem to know nothing about agriculture and they most likely will not notice the contribution and importance of taking agriculture. These findings agree with what is said by Chiu, (2016) as well as Lin and Liou (2019) who state that prior knowledge and skills are the other contextual factors that impact the students' learning of agricultural programmes. 


\subsection{Prior experience}

To explore the students' prior experience, the learners were presented with three items that probe their prior experience. Table 3 below shows the students' responses.

Table 3: Prior experience

\begin{tabular}{|c|c|c|c|c|c|c|c|c|c|c|c|}
\hline \multicolumn{3}{|c|}{ Categories } & \multicolumn{2}{|l|}{ SD } & \multicolumn{2}{|l|}{$\mathrm{D}$} & \multicolumn{2}{|l|}{$\mathrm{N}$} & \multicolumn{2}{|l|}{ A } & \multirow[t]{2}{*}{ SA } \\
\hline$\underset{⿱}{\frac{2}{5}}$ & Prior experience & $f$ & $\%$ & $f$ & $\%$ & $f$ & $\%$ & $f$ & $\%$ & $f$ & \\
\hline 1. & $\begin{array}{l}\text { Agriculture was one of my } \\
\text { major subjects at school. }\end{array}$ & 6 & $3 \%$ & 5 & $3 \%$ & 13 & $5 \%$ & 60 & $25 \%$ & 153 & $64 \%$ \\
\hline 2. & $\begin{array}{l}\text { Agriculture practices at home } \\
\text { have encouraged me to } \\
\text { pursue agricultural studies. }\end{array}$ & 14 & $6 \%$ & 12 & $5 \%$ & 31 & $13 \%$ & 105 & $44 \%$ & 78 & $32 \%$ \\
\hline 3 & $\begin{array}{l}\text { Agriculture was my first } \\
\text { career choice. }\end{array}$ & 11 & $5 \%$ & 11 & $5 \%$ & 23 & $10 \%$ & 92 & $38 \%$ & 101 & $42 \%$ \\
\hline
\end{tabular}

The analysis of Table 3 above indicates the students' responses to item 1 that most students (64\%) have strongly agreed and $25 \%$ agreed that they studied agriculture as their major subject at school. The other results indicated that $5 \%$ of the students remained neutral, while $(3 \%)$ of the students have strongly disagreed and disagreed that they studied agriculture as their major subject in their previous schools. The results show that a high percentage of the students have prior experience in agriculture as they have studied the subject before furthering their studies in the colleges. Item 1 means that the students who have majored in agriculture in their previous schooling have possessed prior experience in agriculture as shown by the majority of students who agree $(25 \%)$ and strongly agree $(64 \%)$. Students who experienced agriculture before will most likely perform better during their studies and many of them became more active in agricultural activities than those who did not. Those with 3\% (SD) and 3\% (D) represent those who did not experience agriculture before, and they are most unlikely to possess prior experience in agriculture during their studies. The neutral ones (5\%) seem to know nothing about agriculture and most like they have never studied agriculture before.

Item 2 indicated that $32 \%$ of the students have strongly agreed, while $44 \%$ agreed that home-based practices encourage students to study agriculture. The other results indicated that a total of $13 \%$ of the students remained neutral, while $5 \%$ disagreed and 6\% strongly disagreed that home-based practices encourage students to study agriculture. The results show that a high percentage of the students have prior experience which was influenced by home-based agricultural practices, and these encouraged them to pursue agricultural studies at the college level. Item 2 means that the students who have practiced agriculture at home dare to further their studies in agriculture as shown by the majority of the students who agree $(44 \%)$ and strongly agree $(32 \%)$. A child who has been exposed to agriculture at home will most likely have prior experience that is related to agricultural activities and is most likely to pursue agricultural studies further to the tertiary level. Those with 5\% (SD) and 6\% (D) represent those who did not practice agriculture at home and are most likely discouraged to pursue 
agricultural studies. The neutral ones $(13 \%)$ seem to know nothing on whether practicing agriculture at home can encourage or discourage one to further pursue agricultural studies or not.

Item 3 indicated that most students (42\%) have strongly agreed and 38\% agreed that agriculture was their first career choice. The other results indicated that $10 \%$ of the students remained neutral, while 5\% strongly disagreed and the other 5\% disagreed that agriculture was their first career choice. The results show that a high percentage of the students' prior experience was influenced by their firstcareer choice such as agriculture. Item 3 means that most of the students with prior experience chose agriculture as their first career choice as shown by the majority of students who agreed (38\%) and strongly agreed (42\%). A child who has grown in an agricultural environment and is exposed to agricultural activities will most likely choose agriculture as a first career choice because this is what they want to achieve as a first choice. The 5\% and 5\% represent those who did not choose agriculture and they are most unlikely to choose agriculture as their first career choice. The neutral ones $(10 \%)$ seem to know nothing about whether they choose agriculture as their first career choice or not. These findings are in harmony with Romberger (2018); Stair, Danjean, Blackburn and Bunch (2016); as well as with Ingram, Sorensen, Warnick and Lawver (2018) that contextual factors such as prior experience have a positive influence on the career choice of learning agricultural programmes.

\subsection{Personality traits}

To explore the students' personality traits, the students were presented with 2 items that probed the impact of the personality traits on the learning of agricultural programmes.

Table 4: Personality traits

\begin{tabular}{|c|c|c|c|c|c|c|c|c|c|c|c|}
\hline & Categories & SD & & $\mathrm{D}$ & & $\mathrm{N}$ & & & & $S$ & \\
\hline$\underset{\Xi}{ \pm}$ & Personality traits & $f$ & $\%$ & $f$ & $\%$ & $f$ & $\%$ & $f$ & $\%$ & $f$ & $\%$ \\
\hline
\end{tabular}

1. Personality traits played a major role in choosing agricultural $15 \quad 6 \% \quad 22 \quad 10 \% \quad 38 \quad 16 \% \quad 82 \quad 34 \% \quad 81 \quad 34 \%$ studies.

2. Students' personality traits towards agriculture have led to low enrolment into vocational $11 \quad 5 \% \quad 26 \quad 11 \% \quad 21 \quad 9 \% \quad 76 \quad 32 \% \quad 106 \quad 43 \%$ agriculture programmes.

After analysing the students' responses to item 1, 34\% of the students have strongly agreed and 34\% agreed that personality traits have played a major role in choosing agricultural studies. The other results indicated that $16 \%$ of the students remained neutral, while 10\% disagreed and 6\% strongly disagreed that personality traits have played a major role in choosing agricultural studies. The results show that a high percentage of the student's personality traits contributed 
to the students choosing agricultural studies. Item 1 means that the personality traits and the environment play a major role in the choice of a career as shown by the majority of students who agree (34\%) and strongly agree (34\%). A child who has grown in an agricultural environment will most likely choose agriculture as a career because this is what they see every day. The $6 \%$ and $10 \%$ represent those who were not exposed to agriculture, and they are most unlikely to choose agriculture as a career. The neutral ones $(16 \%)$ seem to know nothing and most likely they will not take agriculture as a career.

Table 4 indicated that most students (43\%) have strongly agreed and 32\% agreed that the students' personality traits towards agriculture could lead to low enrolment into vocational agriculture programmes. The other results indicated that $9 \%$ of the students remained neutral, while $11 \%$ disagreed and $5 \%$ strongly disagreed that the students' personality traits towards agriculture could lead to low enrolment into vocational agriculture programmes. The results show that a high percentage of the student's positive personality traits influenced them to enrol in vocational agriculture programmes. Item 2 means that the personality traits towards agriculture play a vital when one had to choose to enrol in agricultural programmes as shown by the majority of students who agree (32\%) and strongly agree $(43 \%)$. A child who has never been exposed to agriculture can develop personality traits towards agriculture programmes and that can lead to low enrolment in learning institutions. The 5\% and $11 \%$ represent those who strongly disagree and agree that personality traits have nothing to do with the students' enrolment. The neutral ones (19\%) seem to be unaware of the students' personality traits towards enrolling in agricultural programmes. These findings are in harmony with Foreman, Smalley and Retallick (2018); Mtemeri (2017) that personality traits influence the students towards learning agricultural programmes.

\section{Conclusion}

The study investigated the impact of contextual factors on learning agricultural programmes in TVET colleges. The findings of this study revealed that there are contextual factors that influence the learning of agricultural programmes. Firstly, the study found that the contextual factors such as prior knowledge and skills impact the students' learning of agricultural programmes. The majority of the students indicated that they chose to study agriculture because of their prior agricultural knowledge and skills. For example, the majority of the students indicated that their prior knowledge and skills help them to understand that agricultural programmes help to alleviate poverty, create jobs, and minimise inequality. Secondly, the study found that the other contextual factors such as prior experience have a positive influence on career choice and on the learning of agricultural programmes. For instance, the majority of the students indicated that their previous agriculture studies at high school level influenced them to take agriculture as their first-choice career. Lastly, the study found that personality traits influence students towards learning agricultural programmes. For instance, the majority of the students were influenced by personality traits to choose agricultural studies. These findings can guide recruitment efforts at TVET colleges to look for the students' knowledge and skills, prior experience, and personality 
traits during the recruitment process. As such, the policy leaders can promote and encourage all the schools to incorporate agriculture programmes into early school curriculums as these findings can influence the students to further their agricultural studies to a higher level. The study also recommends that upon recruiting students, contextual factors such as prior knowledge and skills, prior experience as well as personality traits should be tested. However, a new exploration must be carried to investigate other potential contextual factors that are related to the learning of agricultural programmes.

\section{Study limitations}

In this research, three sections of limits are discussed. Firstly, also it is important to cross-check the current findings. Most of the results that the researchers arrived at were discussed in the previous study. For instance, Chiu (2016); Lin and Liou (2019) said that the other contextual factors that impact the student's learning of agricultural programmes include prior knowledge and skills, which is something the researcher has found out in this study. But the researcher's understanding is that continuous improvement is very important because it goes along with time. Secondly, referring to other factors that may reveal other results, the researcher could not get other factors that could have influenced the results. Lastly, calling for the teachers' outlooks could be convenient too. The researcher tried to discuss the results with the lecturers, but they did not have the interest, neither did they have the willingness to do so. Had they allowed the researcher to discuss with them, maybe the results might have been different.

\section{References}

Adebo, G. M., \& Sekumade, A. B. (2013). Determinants of career choice of Agricultural profession among the Students of the Faculty of Agricultural Sciences in Ekiti State University, Nigeria. Journal of agricultural extension and rural development, 5(11), 249-255.

Ahmed, K. A., Sharif, N., \& Ahmad, N. (2017). Factors influencing students' career choices: Empirical evidence from business students. Journal of Southeast Asian Research, 2017, 1-15. https:// doi.org/10.5171/2017.718849

Ariani, D. W. (2013). Personality and learning motivation. European Journal of Business and Management, 5(10), 26-38.

Ary, D., Jacobs, L. C., Razavieh, A., \& Sorensen, C. (2006). Introduction to research in education. Thomson Wadsworth. Belmont, CA.

Beatson, N. J., Berg, D. A., \& Smith, J. K. (2020). The influence of self-efficacy beliefs and prior learning on performance. Accounting \& Finance, 60(2), 1271-1294. https://doi.org/10.1111/acfi.12440

Bilal, Z. O., \& Hussien, M. A. (2019). The impact of entrepreneurship education and previous experience on students' career intentions in Oman? Evidence from Dhofar University. International Journal of Management Research and Reviews, 9(3), 1-9.

Botha, M. (2020). Prior entrepreneurial exposure and action of women entrepreneurs: exploring the moderation effects of entrepreneurial competencies in a developing country context. Frontiers in psychology, 11, 922. https://doi.org/10.3389/fpsyg.2020.00922 
Chiu, T. K. (2016). Effects of prior knowledge on mathematics different order thinking skills in mobile multimedia environments. In Mobile learning design (pp. 373-386). Springer, Singapore. https://doi.org/10.1007/978-981-10-0027-0_22

Chiu, T. K. (2016). Prior Knowledge and Mathematics Different Order Thinking Skills in Multimedia Learning. Singapore: International Society of the Learning Sciences.

Choi, Y. S., \& Lim, U. (2017). Contextual factors affecting the innovation performance of manufacturing SMEs in Korea: A structural equation modeling approach. Sustainability, 9(7), 1193. https://doi.org/10.3390/su9071193

Dang, T. K. A. (2017). Exploring contextual factors shaping teacher collaborative learning in a paired placement. Teaching and teacher education, 67, 316-329. https://doi.org/10.1016/j.tate.2017.06.008

Deng, Z., Guan, H., Huang, R., Liang, H., Zhang, L., \& Zhang, J. (2017). Combining ModelBased \$ Q \$-Learning With Structural Knowledge Transfer for Robot Skill Learning. IEEE Transactions on Cognitive and Developmental Systems, 11(1), 26-35. https://doi.org/10.1109/tcds.2017.2718938

Ekong, J. (2018). Review of the Learning Alliance for Adaptation in Smallholder Agriculture.

Ettis, S. A., \& Kefi, M. K. (2016). Entrepreneurial intentions amongst Tunisian students: An empirical investigation applying the big-five personality traits theory. International Journal of Higher Education Management, 3(1).

Faulkner, P. E., Baggett, C. D., Bowen, C. F., \& Bowen, B. E. (2009). Attitudes, Educational, and Career Choices of Food and Agricultural Sciences Institute Participants. Journal of Agricultural Education, 50(1), 45-56. https://doi.org/10.5032/jae.2009.01045

Fizer, D. (2013). Factors affecting career choices of college students enrolled in agriculture. A research paper presented for the Master of Science in Agriculture and Natural Science degree at The University of Tennessee, Martin, 51-54.

Foreman, E. A., Smalley, S. W., \& Retallick, M. S. (2018). Factors that Influence New Students' Decision to Attend Two Midwestern Land-Grant Universities. NACTA Journal, 62(4), 329.

Gay, L. R., Mills, G. E., \& Airasian, P. (2009). Educational research: Competencies for analysis and applications (9th ed.). Upper Saddle River, NJ: Pearson.

Hoover, B. A. (2020). Factors That Influence How Participants of Virginia's Governor's School for Agriculture Think About, Perceive and Engage with Agriculture and Agricultural Careers [Doctoral dissertation, Virginia Tech].

Hoyle, T. L. (2017). The Relationship between Involvement in the National FFA Organization and the Career Decision Self-Efficacy of College of Agricultural And Life Sciences Students [Doctoral dissertation, University of Idaho].

Imran, A. I., \& Pamungkas, I. N. A. (2016, January). Conceptualizing the Impact of Contextual Communication Factors on Organizational Learning in Higher Learning Institutions. In International Conference on Transformation in Communication (ICOTIC).

Ingram, M. L., Sorensen, T. J., Warnick, B. K., \& Lawver, R. G. (2018). The Influence of School-Based Agricultural Education on Preservice Agriculture Teachers' Choice to Teach. Journal of Agricultural Education, 59(2), 64-78. https://doi.org/10.5032/jae.2018.02064

International Center for Tropical Agriculture. (2015). Learning Alliance for Adaptation in Smallholder Agriculture. Annual Work-Plan and Budget. Cali: CIAT.

International Fund for Agricultural Development. (2016). ASAP Knowledge management and South-South exchanges in ASAP. IFAD PowerPoint presentation. Kigali: IFAD. 
James, O. J., \& Denis, O. (2015). Factors influencing career choice among undergraduate Students in an African university context: The Case of Agriculture Students at Makerere University. Uganda. Journal of Dynamics in Agricultural Research, 2(2), 1220.

Kamal, A., \& Radhakrishnan, S. (2019). Individual learning preferences based on personality traits in an E-learning scenario. Education and Information Technologies, 24(1), 407-435. https://doi.org/10.1007/s10639-018-9777-4

Kenderdine, S. E., Spooner, H. S., Jousan, F. D., Herrin, A. L., \& Hoffman, R. M. (2019). College and career plans of horse-oriented youth. Journal of Equine Veterinary Science, 76, 115-116. https://doi.org/10.1016/j.jevs.2019.03.176

Lawrence, M. N. (2016). Factors contributing toward attrition of engineering students at public vocational colleges in the Western Cape [Doctoral dissertation, Cape Peninsula University of Technology].

Liaw, S. Y., Wu, L. T., Chow, Y. L., Lim, S., \& Tan, K. K. (2017). Career choice and perceptions of nursing among healthcare students in higher educational institutions. Nurse education today, 52, 66-72. https://doi.org/10.1016/j.nedt.2017.02.008

Lin, J. J., \& Liou, P. Y. (2019). Assessing the learning achievement of students from different college entrance channels: a linear growth curve modelling approach. Assessment \& Evaluation in Higher Education, 44(5), 732-747. https:// dx.doi.org/10.1080/02602938.2018.1532490

Malema, R. N., \& Muthelo, L. (2018). Literature review: Strategies for recruitment and retention of skilled healthcare workers in remote rural areas. EQUINET (Harare) and University of Limpopo (South Africa) Report, (115).

Marx, A. A., Simonsen, J. C., \& Kitchel, T. (2014). Secondary agricultural education program and human influences on career decision self-efficacy. Journal of Agricultural Education, 55(2), 214-229. https://doi.org/10.5032/jae.2014.02214

Marx, A. A., Smith, A. R., Smalley, S. W., \& Miller, C. (2017). Previous experience not required: Contextualizing the choice to teach school-based agricultural education. $\begin{array}{llll}\text { Journal of Agricultural Education, } & \text { 58(4), } & 126 .\end{array}$ https://doi.org/10.5032/jae.2017.04126

McCarthy, K. S., \& McNamara, D. S. (2021). The multidimensional knowledge in text comprehension framework. Educational Psychologist, 1-19. https://doi.org/10.1080/00461520.2021.1872379

Meddour, H., Abdo, A. A., Majid, A. H., Auf, M. A., \& Aman, A. M. (2016). Factors Affecting Career Choice among Undergraduate Students in Universitas Indonesia. International Journal of Economic Perspectives, 10(4).

Mitzel, H. E. (1969). Teacher Effectiveness. In C. W. Harris (Ed) Encyclopaedia of Educational Research (3 ${ }^{\text {rd }}$ edition, pp. 1481-1486) New York; Macmillan.

Mogensen, F., \& Schnack, K. (2010). The action competence approach and the 'new'discourses of education for sustainable development, competence and quality criteria. Environmental education research, 16(1), 59-74. https:// doi.org/10.1080/13504620903504032

Morss, E. R. (2019). Implementing rural development projects: Lessons from AID and World Bank Experiences. Routledge. https://doi.org/10.4324/9780429050091-3

Mothokoa, N. B., \& Maritz, J. (2018). Recognition of prior learning candidates' experiences in a nurse training programme. Health SA Gesondheid, 23(1). https:// doi.org/10.4102/hsag.v23i0.1080

Mtemeri, J. (2017). Factors influencing the choice of career pathways among high school students in Midlands Province, Zimbabwe [Doctoral dissertation, University of South Africa, Pretoria, South Africa]. 
Palmer, T. A., Burke, P. F., \& Aubusson, P. (2017). Why school students choose and reject science: A study of the factors that students consider when selecting subjects. International Journal of Science Education, 39(6), 645-662. https://doi.org/10.1080/09500693.2017.1299949

Pasha, A., \& Siddiqui, D. A. (2019). Factors Influencing Professional Selection Choices: Evidence from Pakistan. http://dx.doi.org/10.2139/ssrn.3641642

Perry, B. L. (2018). Factors Associated with Intent to Practice Conventional or Organic Farming among Students Majoring in Agriculture [Doctoral dissertation, D'Youville College].

Picazo-Vela, S., Chou, S. Y., Melcher, A. J., \& Pearson, J. M. (2010). Why provide an online review? An extended theory of planned behavior and the role of Big-Five personality traits. Computers in Human Behavior, 26(4), 685-696. https://doi.org/10.1016/j.chb.2010.01.005

Ramson, P., Govender, P., \& Naidoo, K. (2016). Recruitment and retention strategies for public sector optometrists in KwaZulu-Natal Province, South Africa. African Vision and Eye Health, 75(1), 1-10. https:/ / doi.org/10.4102/aveh.v75i1.349

Romberger, D. J. (2018). The influence of secondary agricultural education student supervised agricultural experience participation on career decision self-efficacy.

Salzwedel, A., Heidler, M. D., Meng, K., Schikora, M., Wegscheider, K., Reibis, R., \& Völler, H. (2019). Impact of cognitive performance on disease-related knowledge six months after multi-component rehabilitation in patients after an acute cardiac event. European journal of preventive cardiology, 26(1), 46-55. https://doi.org/10.1177/2047487318791609

Sephokgole, R. D., \& Ramaligela, S. M. (2021). Challenges experienced by lecturers about instructional practices on agricultural programmes in TVET colleges. In New Models for Technical and Vocational Education and Training (pp. 49-73). IGI Global. https:// doi.org/10.4018/978-1-7998-2607-1.ch004

Singh, J. P., Fazel, S., Gueorguieva, R., \& Buchanan, A. (2014). Rates of violence in patients classified as high risk by structured risk assessment instruments. The British Journal of Psychiatry, 204(3), 180-187. https:/ / doi.org/10.1192/bjp.bp.113.131938

Sosa, E. (2015). Judgment and agency. Oxford University Press, USA. https://doi.org/10.1093/acprof:oso/9780198719694.003.0003

Stair, K., Danjean, S., Blackburn, J. J., \& Bunch, J. C. (2016). A major decision: Identifying factors that influence agriculture students' choice of academic major. Journal of Human Sciences and Extension, 4(2).

Stajkovic, A. D., Bandura, A., Locke, E. A., Lee, D., \& Sergent, K. (2018). Test of three conceptual models of influence of the big five personality traits and self-efficacy on academic performance: A meta-analytic path-analysis. Personality and individual differences, 120, 238-245. https:/ / doi.org/10.1016/j.paid.2017.08.014

Taçgın, Z. (2020). The perceived effectiveness regarding Immersive Virtual Reality learning environments changes by the prior knowledge of learners. Education and Information Technologies, 25(4), 2791-2809. https://doi.org/10.1007/s10639-01910088-0

Tanga, M., \& Maphosa, C. (2018). Exploring the recruitment and training of peer facilitators in a South African University. International Journal of Educational Development, 61, 196-203. https://doi.org/10.1016/j.ijedudev.2017.08.005

Thieman, E. B., Rosch, D. M., \& Suarez, C. E. (2016). Consideration of Agricultural Education as a Career: A Statewide Examination by High School Class Year of Predicting Factors. Journal of Agricultural Education, 57(4), 29-43. https://doi.org/10.5032/jae.2016.04029 
Thwala, W. M. (2017). Agriculture Vocational Education Programme and the Promotion of Job Creation Skills in the Free State Technical Vocational Education and Training College [Doctoral dissertation, University of Fort Hare].

Wati, M., Pasani, C. F., \& Dewantara, D. (2018, February). Physics Problem Solving Skill Based on Students Prior Knowledge. In First Indonesian Communication Forum of Teacher Training and Education Faculty Leaders International Conference on Education 2017 (ICE 2017). Atlantis Press. https://doi.org/10.2991/ice-17.2018.81

Woeber, K., \& Sibley, L. (2018). The Effect of Prior Work Experiences on the Preparation and Employment of Early-Career Midwives. Journal of midwifery $\mathcal{E}$ women's health, 63(6), 668-677. https://doi.org/10.1111/jmwh.12910

Xhomara, N. (2020). How prior knowledge, learning, teaching and assessment affect students' achievements in Mathematics. Research in Education and Learning Innovation Archives, (25), 68-91.

Yarden, H., \& Yarden, A. (2010). Learning using dynamic and static visualizations: students' comprehension, prior knowledge and conceptual status of a biotechnological method. Research in Science Education, 40(3), 375-402. https:// doi.org/10.1007/s11165-009-9126-0

Zhang, J., \& Ziegler, M. (2018). Why do personality traits predict scholastic performance? A three-wave longitudinal study. Journal of Research in Personality, 74, 182-193. https://doi.org/10.1016/j.jrp.2018.04.006

Zulu, W. V. (2018). Student's attrition in TVET colleges: a case study of Elangeni TVET College in South Africa [Doctoral dissertation].

Zwane, M., \& Setlalentoa, W. N. (2020). Investigating factors hindering the implementation of e-learning at motheo technical and vocational education and training (TVET) college: a case study of the national vocational certificate (NCV) programme. Education and New Developments, 363. https://doi.org/10.36315/2020end077 